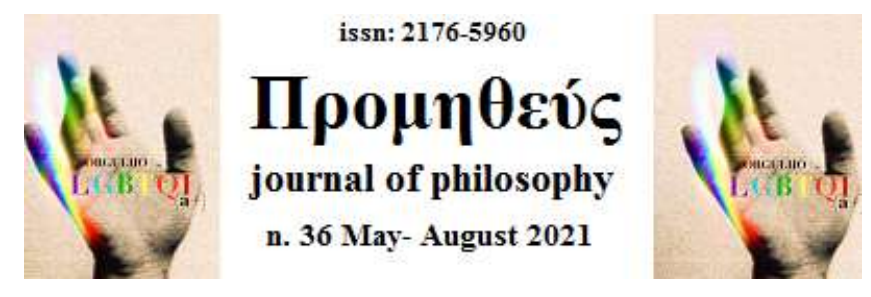

\title{
CONCEITOS BÁSICOS DA ÉTICA ESTOICA
}

\author{
GLEYWBLISTON DE SOUZA RESENDE ${ }^{1}$
}

\begin{abstract}
Resumo: Na filosofia do pórtico, existe uma grande preocupação com o aspecto ético moral dos seres humanos, em sua doutrina ética, os estoicos nos exortam a viver de acordo com a natureza, esse é o ponto máximo que alguém pode alcançar em termos de excelência humana, para o estoicismo. Viver segunda a natureza implica, viver segundo nossa natureza racional e a inteligência universal, precisamos conhecer de modo profundo todos os aspectos de nossa condição humana, para podermos agir em acordo com nossa natureza racional. Para os estoicos a essência humana é racional, desse modo o homem deve realizar sua natureza através de uma vida guiada pela razão, e esse aspecto humano o coloca como um ser capaz de escolher e assim decidir-se por uma determinada forma de agir, o que torna as ações humanas racionais, éticas e morais. Na busca pela compreensão da natureza humana os estoicos, identificam um impulso primário que condiciona os seres à ação, que orienta os mesmos, a buscarem as coisas que lhe são benéficas segundo sua natureza e a repulsa às coisas contrárias a natureza. Segundo aos estoicos este princípio da oikeíōsis permanece como um elemento estrutural, porém a racionalidade possibilita ao ser humano, a possibilidade de escolher entre o que está de acordo ou que é contrário a natureza, pelo que podemos pensar na razão como modeladora do impulso, sendo ela e não mais o impulso quem deve orientar nossas ações. Segundo este princípio devemos buscar o que nos é próprio e necessário para nosso pleno desenvolvimento e rejeitar tudo que nos é prejudicial. Para o estoicismo existem coisas boas, más e ainda os indiferentes. O estoico é indiferente às coisas externas, por estas não serem fundamentais para o desenvolvimento humano ou por não contribuírem para sua felicidade.
\end{abstract}

Palavras-Chave: Estoicismo. Ética. Oikeíōsis, Impulso, indiferentes.

In the philosophy of the portico, there is a great concern with the ethical moral aspect of human beings, in their ethical doctrine, the Stoics urge us to live according to nature, this is the maximum point that anyone can reach in terms of human excellence, for stoicism. Living according to nature implies, living according to our rational nature and universal intelligence, we need to know in depth all aspects of our human condition, so that we can act in accordance with our rational nature. For the Stoics, the human essence is rational, so man must realize his nature through a life guided by reason, and this human aspect places him as a being able to choose and thus decide for a certain way of acting, the that makes human actions rational, ethical and moral. In the search for understanding human nature, the Stoics identify a primary impulse that conditions beings to action, which guides them to seek the things that are beneficial to them according to their nature and the repulsion to things contrary to nature. According to the Stoics, this principle of oikeíōsis remains a structural element, but

\footnotetext{
${ }^{1}$ Mestre em Filosofia pela Universidade Federal de Sergipe - UFS.
} 
rationality allows the human being the possibility of choosing between what is in agreement or what is contrary to nature, so we can think of reason as a modeler of the impulse, being she and no longer the impulse who should guide our actions. According to this principle, we must seek what is proper and necessary for our full development and reject everything that is harmful to us. For Stoicism there are good things, bad things and even the indifferent ones. The Stoic is indifferent to external things because they are not fundamental to human development or because they do not contribute to his happiness.

\section{INTRODUÇ̃̃̃O}

Neste artigo faremos uma breve análise de alguns dos aspectos fundamentais da ética no estoicismo romano. O estoicismo surgiu em fins do século IV AEC, num período de grande turbulência política, social e crise ético-moral do mundo grego. No século II AEC. chegou a Roma, onde teve grande aceitação por parte da sociedade romana do final do período republicano e nos dois primeiros séculos da fase imperial. A filosofia estoica em Roma se destaca por dois pontos cardiais a ética e a política.

Dentro do mundo cultural romano, o estoicismo sofreu algumas adaptações em sua doutrina. Pánecio de $\operatorname{Rodes}^{2}$, foi uma das principais influências do estoicismo romano. Frequentador do círculo dos Cipiões, o filósofo tanto influenciou a alta sociedade romana como teve sua filosofia influenciada pelo esplendor e pela ostentação dessa civilização. Panécio introduziu algumas mudanças no estoicismo clássico. Seu contato com a mais alta cultura romana promoveu uma abertura em seu pensamento, ao mesmo tempo em que promoveu uma ruptura com seus antecessores. Panécio é reconhecido como um dos representantes mais significativos do estoicismo médio: "Seu pensamento é notável sobretudo em dois aspectos: ele esforçou-se por adaptar a ética estoica aos costumes romanos, de modo a formar uma moral prática [...]; e interessou-se seriamente por Platão e pelo platonismo [...]. (GOURINAT; BARNES, 2013, p. 26). Podemos exemplificar a influência de sua filosofia em autores Marco Túlio Cícero (106 - 43 EC), em seu tratado Dos deveres. O filósofo Cláudio

\footnotetext{
${ }^{2}$ Panécio de Rodes (185 - 110/09 AEC) foi um filósofo estoico discípulo de Diógenes da Babilónia e de Antípatro de Tarso, antes de viajar para Roma. Tornou-se conselheiro filosófico e amigo de Cipião. O filosófo de Rodes foi influente na introdução das doutrinas estoicas na Roma imperial. Com a morte de Cipião em 129, regressou à escola estoica em Atenas, tendo sido o seu último escolarca. Com Panécio, o estoicismo tornou-se mais ecléctico. A sua obra mais famosa foi "Sobre os Deveres", a fonte principal de Cícero na sua própria obra com o mesmo nome. Também foram de sua autoria Da Providência e um comentário ao Timeu de Platão. Porém de suas obras restaram apenas fragmentos e referências doxografias. Aderiu às doutrinas políticas de Platão e Aristóteles, advertindo para as formas mistas de governo.
} 
Galeno (129 - 199 ou 217 EC), em um de seus diálogo intitulado Da inutilidade de afligir-se, faz alusão ao "Platão de Pánecio". 3

Em seu estoicismo, modificou alguns aspectos como a valorização da ética prática, os bens, os deveres, aspectos da física, e o sentido político. Na ética, amenizou a rigidez idealizada do estoicismo antigo, a rigidez teórica, flexibilizando-a frente à necessidade da prática, admitindo-se o caráter cambiante dos fatos. Pánecio direciona os discursões antes centradas entre uma postura rígida entre vicio e virtude voltando-se para uma flexibilização e reflexão sobre os indiferentes. Abandonando, por conseguinte a apatia e a mortificação, para os céticos e os estoicos, estado de insensibilidade emocional ou esmaecimento de todos os sentimentos, alcançado mediante o alargamento da compreensão filosófica a alegria de viver. Escreveu sobre o ócio, a tranquilidade da alma e a providência, temas próprios do espírito estoico romano. "Panécio não tematizou a superioridade da virtude prática sobre a teórica, [...], ele valorizou a vida prática, trouxe ao Pórtico um vivo sentido da sociabilidade [...], que absorveu dos romanos [...].” (REALE, 1994, p. 372).

Dentro do sistema filosófico estoico, há uma subdivisão da doutrina em três campos, são eles a física, a lógica e a ética, no qual todas as partes estão integradas, dando corpo e significado ao discurso filosófico da Stoa como nos demostra Diógenes: "E nenhuma parte é separada das outras, [...], mas ao contrário todas estão estreitamente unidas entre si. Seu próprio ensino fazia-se conjuntamente. (LAÉRCIO, 1988, p. 40). Vários dos elementos das concepções estoicas integraram-se à visão de mundo e a conceitos da tradição romana, demostrando sua capacidade de adequação a diversidade social e cultural, o que favoreceu sua difusão, consolidando assim seu aspecto cosmopolita. No período imperial, o Estoicismo preocupa-se sobretudo com as questões éticas. A filosofia do Pórtico está dividida entre a física, a lógica e a ética, que devem ser estudadas em conjunto, não havendo uma separação ou hierarquia entre as "partes" que a compõe. "Porém, [...] à exceção de Aríston de Quios, bem como de Sêneca, todos os estoicos consideram fundamental o estudo da lógica" (DINUCCI, 2020, p. 99). Podemos inferir sobre a doutrina estoica utilizando as seguintes metáforas: as partes da filosofia são comparadas a um ovo, do qual a casca seria a lógica; a clara, a ética; a gema, a física. E ainda a um campo fértil, do qual a cerca seria a lógica; a terra ou as árvores, a física; e os frutos, a ética (LAÉRCIO, 1988, p. 39-41). Um dos aspectos que Diógenes deixa transparecer é de que não há como estabelecer um ponto de interrupção entre as partes, como demostra Ribeiro:

\footnotetext{
3 Para um maior aprofundamento conferir em: GOURINAT, J. B.; BARNES, J. (Orgs.). Ler os Estóicos. Tradução de Paula S. R. C. Silva. São Paulo: Loyola, 2013, p. 26.
} 
Estuda-se física para saber como as coisas são e assim disciplinar o agir em função daquilo que, de acordo com aquela ontologia, é legítimo e necessário buscar, repelir ou nem buscar nem repelir. A lógica é uma propedêutica. Inclui não só aquilo que hoje se chama 'lógica', mas também gramática, fonética, retórica, e, isso é importantíssimo, teoria do conhecimento. A ideia é que é preciso saber como as coisas são (física) para saber como agir (ética), mas para fazer física é preciso estar consciente de que critérios devem pautar a investigação, de que cânones permitem incorporar certas proposições ao corpo da doutrina ou rejeitá-las. Ora, a física e a ética são discursos; é preciso conhecer, portanto, os princípios que regem o discursar, o que pode incluir: a gramática da língua natural, a arte de expor um tópico a um auditório, o nexo de necessidade interno que liga certas proposições do ponto de vista formal, o modo como um som se torna significante e o modo como o significado apreende o ser das coisas (RIBEIRO, 2008, p. 141.)

O estoicismo apresenta sua filosofia de maneira tripartida fazendo um esboço pedagógico de seu sistema filosófico. Essas imagens ilustram a função de cada parte da filosofia: a lógica estabelece os contornos e os limites nos quais a doutrina se movimenta, tendo a função de orientar o conhecimento; a física é o fundamento da doutrina; já a ética é o seu coroamento, o resultado a que se chega à busca de uma vida coerente com o cosmo e, portanto, racional e feliz. As metáforas ilustrativas do pensamento estoico facilitam sua compreensão ao mesmo tempo em que, apesar de ser possível se fazer uma divisão eles, apresentam cum todo organizado em que as partes se complementam entre si, não sendo possível a recusa de uma das partes, o que levaria a incompreensão de toda a teoria. Portanto não podemos conceber uma separação das “partes”, pois todas estão interligadas entre si.

Dentro da estrutura filosófica da Stoá, o ser humano é parte do universo e, na busca da vida moral, o ser humano deve estar em consonância com a razão (inteligência) universal, responsável pela harmonia cósmica. Os seres humanos devem orientar suas vidas pelas leis e pelo princípio ordenador do cosmos. Podemos inferir que, no pensamento estoico, há uma grande importância dada ao indivíduo em sua relação com consigo e com o mundo que o cerca, o que é fundamental na concepção da ética. Essa relação é estabelecida de modo natural, em um processo universal a todos os seres denominado de oikeíōsis ${ }^{4}$. Nesse processo de tomada de consciência de si e da realidade que os cerca, os seres vivos tornam-se

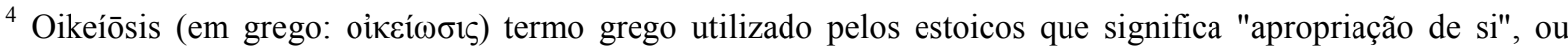
"adaptação instintiva", é a relação da pessoa consigo mesma e com o mundo, que permite distinguir de forma imediata as diferenças de valor entre objetos úteis e bons, por um lado, e por outro lado os objetos nefastos. Familiarizar-se, impregnar-se de estímulos dos sentidos, reconhecer-se como "cidadão do mundo". Ele estabelece nos seres o instinto de autopreservação através da synaesthesis, ou a percepção interna, realizando nos seres uma ação nos seres a buscar tudo quanto é capaz de conservá-lo, de evitar aquilo que lhe é contrário e de conciliar-se consigo mesmo e com as coisas que são conforme à própria natureza.
} 
familiares a si mesmos e ao meio que os rodeia. Segundo Reale, em sua obra intitulada a História da filosofia:

Todos os seres vivos são dotados de um princípio de conservação (chamado oikeíōsis), que instintivamente os leva a evitar aquilo que os prejudica e a procurar aquilo que os beneficia, que acresce ao seu ser: numa palavra, o bem de um ser é aquilo que lhe é benéfico, e o mal é o que danifica. Por conseguinte, todo ser vivo pode e deve viver segundo a natureza, segundo a sua natureza. Ora, a natureza do homem é racionai e a sua essência e a razão. Assim, para o homem atuar o princípio de conservação deve buscar as coisas e apenas as coisas que incrementam a sua razão e fugir das que o prejudicam. (REALE; ANTISERI, 2007, p. 288).

O princípio de autopreservação nasce da percepção dos seres, estabelecendo nestes um padrão de ações e comportamentos que lhes são próprios. Estas ações e comportamentos têm por objetivo o desenvolvimento e a preservação do seu próprio ser, buscando aquilo que é próprio ao seu pleno desenvolvimento, para conservá-lo e aprimorar suas aptidões naturais ao meio em que vive e ter repulsa a tudo que seja prejudicial a esse desenvolvimento de acordo com sua própria natureza. Segundo Diógenes Laércio, Crisipo, em sua obra Dos Fins, afirma que,

\footnotetext{
Não se pode admitir logicamente que a natureza torne o ser vivo estranho a si mesmo [...], nem que o trate como um estranho, nem que não o tenha como sua criatura. [“...], constituindo o ser vivo, fê-lo caro a si mesmo, pois assim ele repele tudo que lhe é prejudicial, e lhe acolhe tudo que é útil e afim”. (LAÉRCIO, 1988, p. $85)$.
}

A oikéiōsis é o impulso que possibilita a familiaridade dos seres com seus pares e os torna aptos a si mesmos e ao meio em que vivem, impulsionando-os a buscarem o que é bom e repelindo o que lhes prejudica. Nos seres humanos, existe um instinto de autopreservação, assim como nos outros animais. Porém, enquanto estes são levados a seguir seus impulsos para sua autopreservação, nos seres humanos este impulso está além das necessidades de abrigo, alimentação, proteção e a própria sobrevivência etc. E continua Diógenes Laércio "E já que os seres racionais receberam a razão com vista a uma conduta mais perfeita, sua vida segundo a razão coincide exatamente coma existência segundo a natureza, enquanto a razão se agrega a eles como aperfeiçoadora do impulso.” (LAÉRCIO, 1988, p. 85.)

A doutrina estoica da oikeíōsis tem como base os instintos naturais, sua recepção e sua racionalização, buscando compreender a natureza das ações humanas. Como podemos notar, a oikeíōsis traz consigo implicações éticas para os seres humanos, pois a capacidade racional 
possibilita ao ser humano a liberdade da escolha, o que implica que nossas ações devem ser conduzidas segundo nossa razão, para que estejam de acordo com a natureza.

No pensamento estoico, existe uma estreita relação entre a física e a ética, que se fundamenta na compreensão dos impulsos que compõem a natureza humana. Portanto, não se trata de uma exposição das obrigações morais, mas por buscar compreender os agentes condicionadores das ações humanas. A natureza humana faz parte de uma ordem, e estamos submetidos a essa lei. Através do princípio da oikeíōsis, o ser humano pode realizar sua natureza.

A doutrina da oikéiōsis fundamenta-se na noção de impulso responsável pela ação e, no caso dos seres humanos, o impulso passa a ser transformado ou modelado pela razão. Enquanto nos animais o impulso é determinante em suas ações, nos humanos o impulso é racional, depende do assentimento. Como demostrado por Oliveira;

\footnotetext{
Podemos entender a oikeíōsis como o impulso pelo qual tanto o ser humano quanto os animais e mesmo as plantas tentam tornar o mundo familiar e adaptado a si mesmos, buscando não apenas a autopreservação, mas também tudo aquilo que julgam ser o melhor para si. Nesse sentido, "a natureza, constituindo o ser vivo, fê-lo caro a si mesmo, pois assim ele repele tudo que lhe é prejudicial, e acolhe tudo que lhe é útil e afim". Assim, um ser vivo considera "bom" aquilo que lhe é útil e "mau" o que lhe é prejudicial. A oikeínsis implica em objetivos diferentes para cada tipo de ser vivo. Os impulsos de um animal irracional o levam a procurar alimento, bebida e abrigo. No entanto, o ser humano, como animal racional, necessita preservar não apenas o corpo, mas também a alma, sua racionalidade. [...], pois é ela que o distingue dos animais irracionais. (OLIVEIRA, 2018, p. 45).
}

O primeiro impulso está presente nos seres como mecanismo de autoconservação, direcionando-os a buscar tudo aquilo que lhe for favorável ao seu desenvolvimento segundo a sua natureza, e a repulsa a buscar uma adaptação, uma familiarização consigo e com o mundo que o cerca. O impulso nos animais não racionais é preponderante para suas ações acolhendo tudo que lhes for útil à sua sobrevivência e repelindo o que lhes for prejudicial. Esse princípio de conservação nasce da nossa percepção nos seres, após o nascimento em que se estabelece o reconhecimento de seu corpo, passando pela interação e a apropriação deste, ou seja, da constituição do corpo em um segundo momento tomado o conhecimento de si como resultado dessa interação e por fim, com os objetos externos. Nos também passamos pelo processo em que o impulso é preponderante em nossas ações e na relação com as coisas externas. Segundo Jâmblico, “dizem os estoicos que a razão não surge imediatamente, mais sim que se consolida mais tarde, por volta dos quatorze anos, a partir dos sentidos e das representações" (JÁMBLICO apud SANTOS, 2008, p. 72). A oikeíōsis é intrínseca aos seres e está contida nos organismos por toda sua existência. Nos animais ela é como um impulso que lhes garante 
a sobrevivência, o guia para a autopreservação de si e sua continuidade como espécie, e são totalmente condicionados por este impulso, pelo que suas ações são naturais. Segundo os estoicos período de formação da razão, nos seres humanos, ocorreria entre os sete aos quatorze anos. Antes desse processo, nossas ações, assim como nos animais, são tidas como naturais e não- racionais, ou seja, são de acordo com a natureza, não podendo ser avaliadas como ações morais ou imorais. Isso só será possível apenas com a formação da razão. Segundo Crisipo, "a33 perfeição da razão é, portanto, o bem específico do ser humano, enquanto todos os outros caracteres ele dividiu com os animais e os vegetais". (SVF III 200a (1)). A razão é particular ao ser humano, e devemos viver segundo ela para que possamos alcançar o bem, que seria viver de maneira virtuosa e segundo a nossa natureza. O princípio da oikeíōsis permanece como um elemento estrutural, porém a racionalidade possibilita ao ser humano, a possibilidade de escolher entre o que está de acordo ou que é contrário a natureza, pelo que podemos pensar na razão como modeladora do impulso, sendo ela e não mais o impulso quem deve orientar nossas ações. Podemos concluir que a natureza humana, participando da natureza divina, tem apenas impulso para o bem, enquanto o mal seria o resultado do engano advindo de nossas representações e opiniões sobre as coisas e é aí que surgem os vícios.

Como demostrado, a oikeíōsis é fundamental na compreensão da ética no estoicismo, pois ela é a base de toda sua estrutura teórica. Ela é um princípio universal presente em todos os animais. É a tendência que têm de conservarem-se a si mesmos, aproveitando-se de tudo o que é apto de conservar seu próprio ser e evitar tudo o que lhe é contrário e prejudicial. $\mathrm{O}$ primeiro impulso revela a percepção estoica de bem e mal, portanto o bem seria está em que está em consonância com a natureza humana e divina. As coisas são preferíveis se buscam o bem. Desta maneira, o princípio universal da oikeíōsis fundamenta toda a teoria ética no estoicismo. A descoberta de fragmento de papiro na cidade Hermópolis Magna, ${ }^{5}$ no ano 1901,

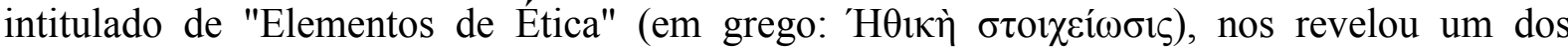
aspectos estruturais da compreensão estoica da oikeíōsis. Esse fragmento é composto por trezentas linhas que tratam do tema da autopercepção, apresentando o argumento de que, desde o nascimento, os animais tomam ciência de si, percebendo a si próprios continuamente, sendo está a primária faculdade dos animais, que teria um papel decisivo no comportamento

\footnotetext{
${ }^{5}$ Cidade do Egito Antigo. Suas ruínas localizam-se a cinquenta quilômetros da atual Mallaui.
} 
dos animais, segundo sua natureza. Todos os animais se comportam de modo a se autopreservarem e não são somente cientes de si próprios, mas também de si próprios em relação a outros animais. O seguinte argumento sobre a autopercepção exposto no pequeno tratado é atribuído ao filosofo Hiérocles ${ }^{6}$, filósofo estoico da primeira metade do século II.

\begin{abstract}
Ora, para os estoicos, a oikeiosis é o processo pelo qual o vivente sensível torna familiar e próprio primeiramente a si mesmo e depois seu entorno imediato. No caso do ser humano, essa "familiarização" ou "apropriação" (termos pelos quais podemos traduzir oikeiosis) pode chegar a abraçar a humanidade inteira, partindo da percepção de si no momento inicial de vida pós-parto. Como nos diz Hiérocles, é no nascimento que a natureza do embrião dos animais se torna mente (psyche), pois os animais percebem a si mesmos desde o primeiro momento após o nascimento (DINUCCI, 2020, p. 77).
\end{abstract}

O início da vida ocorre após o nascimento, é neste momento que o animal toma consciência de si e de suas partes e, pela percepção, aprende o seu funcionamento e, aos poucos, apropria-se do seu corpo e, pela autopercepção, adere ao que lhe é próprio segundo sua natureza, repelindo tudo o que é prejudicial à constituição física de seu ser quanto aos aspectos internos. Essa interação do ser consigo mesmo e com os objetos externos é o que os estoicos chamam de princípio da oikéiosis, que é adquirido por esta relação que cada animal mantém com consigo mesmo e os objetos. Esse processo de apropriação tende a desenvolverse reforçando todos os aspectos próprios a este segundo sua natureza, atribuindolhe uma identidade própria. A doutrina da oikeíōsis, segundo a filosofia estoica, é responsável pelo princípio de identidade dos seres, em que este princípio é o meio pelo qual os animais tomam ciência de si a partir da interação consigo mesmos (autopercepção) e com a percepção dos objetos externos (o mundo). Esse processo é continuo perdurando, por toda a sua existência. Para os seres humanos, esse processo de apropriação e aperfeiçoamento de si é um movimento contínuo, pois o conhecimento racional é produzido e aperfeiçoado constantemente, enquanto nos animais (não-racionais) o conhecimento é vedado, pois lhes basta seguir o impulso. O processo da oikeiosis para nós, e devido à nossa faculdade racional, implica que nossas ações sejam apropriadas segundo a natureza racional que possuímos, pelo que podemos concluir que a doutrina da oikeíōsis traz implicações éticas e morais para o ser humano.

Na obra Sobre os Atos Apropriados o filósofo nos apresenta um desdobramento da oikeiosis humana, como podemos observar na ilustração abaixo.

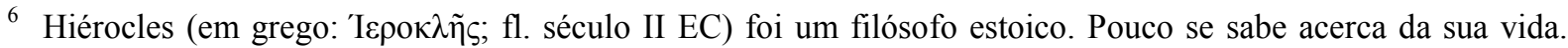
Aulo Gélio menciona-o como sendo seu contemporâneo, e descreve-o como sendo um "homem santo e solene". Outros fragmentos dos escritos de Hiérocles são preservados por Estobeu. ver RAMELLI, Ilaria; KONSTAN, David. Hierocles the Stoic: Elements of Ethics, Fragments, and Excerpts. Atlanta: Cambrige Press, 2009
} 


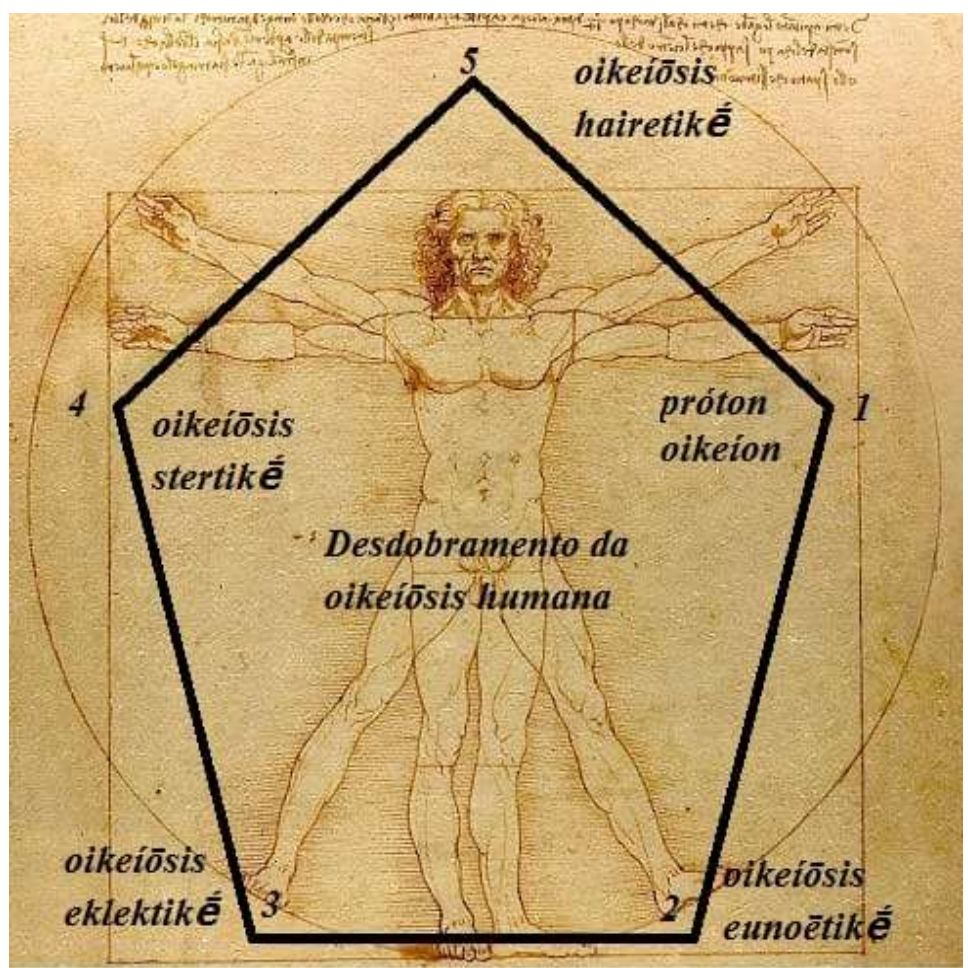

(Figura 1: DINUCI, 2020).

$\mathrm{Na}$ obra podemos perceber uma subdivisão da oikeíōsis humana. Isso não significa que existam tipos diferentes de oikeiosis, mas diversos desdobramentos de um único processo de apropriação. Segundo Dinucci;

[...], Hiérocles afirma haver quatro tipos de oikeiosis nos animais adultos: (a) oikeiosis eunoetike (pela qual o animal torna-se bem-disposto para consigo mesmo); (b) oikeiosis sterktike ("apropriação por afeição"), pela qual o animal se apropria amorosamente daqueles que lhe são próximos por laços de estirpe, a começar pelos filhos27; (c) oikeiosis hairetike ("apropriação por escolha dos bens racionais"), pela qual o ser humano busca as ações apropriadas (ta kathekonta) e os bens morais (as excelências); (d) oikeiosis eklektike, que é a versão genérica da anterior, aplicável a todos os animais, pela qual cada animal seleciona as coisas externas que propiciam sua preservação. [...], não se trata de diferentes apropriações, mas diferentes aspectos, diferentes desdobramentos do mesmo processo de apropriação relativamente a tipos distintos de objetos (i.e. o próprio animal, outros animais, objetos externos, filhos e parentes, etc.), processo que tem como fim a realização da natureza individual. (DINUCCI, 2020, p. 78).

Após o nascimento, o ser humano e os animais (não racionais) tornam-se familiares a si mesmos. Em seguida, familiarizam-se aquilo com o que advém das representações do 
próprio corpo, nas relações que estabelecem a partir dessas representações ${ }^{7}$ através da constituição da psyché ${ }^{8}$ que ocorre após o nascimento. "Em outros termos a percepção de algo externo, que ocorre logo após o nascimento, é simultânea à percepção de si mesmo, como algo distinto do observador" (DINUCCI, 2020, p. 78). Apresentamos em seguida, de modo resumido, a enumeração feita por Hiérocles sobre os tipos de oikeiosis relacionados aos seres humanos. Seguiremos a ordem de exposição proposta na imagem acima:

- Proton oikeion: Momento em que os animais, logo após o nascimento, passam pelo processo de familiarização e apropriação de si, que ocorre a partir da percepção de si mesmos. Consiste no momento básico do processo, pois ocorre no primeiro instante de vida em que há autopercepção interna.

- Oikeiosis eunoetike: Neste segundo momento, o impulso torna-se afeição por si mesmo, aqui os seres são levados ao amor por si mesmos, buscando segundo sua constituição natural sua autopreservação.

- Oikeiosis eklektike: Neste terceiro momento do processo, o impulso volta-se para a seleção do que conduz à autopreservação. Podemos pensar que, neste momento do processo, o animal após estabelecer o que é benéfico para si, seleciona apenas o que favorece sua autopreservação, como certos alimentos, recusando o que lhe parece daninho.

- Oikeiosis sterktike: Neste quarto momento, o despertar do impulso leva à criação de laços afetivos como, por exemplo, entre pais e filhos.

- Oikeiosis hairetike: Por fim, no quinto e último momento da oikeíōsis humana, temos o surgimento dos impulsos morais no ser humano pelos quais se buscam os bens morais.

A oikeíōsis, para os estoicos, ocorre nos humanos como um mecanismo natural compartilhado com os animais irracionais, que tem entre seus efeitos o amor em relação a si e

\footnotetext{
${ }^{7}$ Temos as representações quando a sensação alcança a alma e se sobrepõe ao juízo do logos, que está no hegemônico. Esse juízo se chama assenso e se traduz em um tipo de passagem para o mundo do conhecimento superior, à qual nem todas as representações terão assenso, mas apenas aquelas que foram reconhecidas como catalepticas (= claras e distintas); as outras, as acatalepticas (ou seja, pouco claras) serão relegadas ao campo da fantasia ou da opinião. A representação por si é capaz de induzir no ânimo humano uma reação que pode ser de familiaridade ou de estraneidade. (RADICE, Roberto. Estoicismo. Tradução Alessandra Siedschlag. São Paulo: Ideias \& Letras, 2016., pág.280) ${ }^{8} 14$ Idem (RADICE, Roberto. Estoicismo. Tradução Alessandra Siedschlag. São Paulo: Ideias \& Letras,2016., pág.280)
} 
posteriormente em relação ao outro. Sendo assim, ela é responsável por aspectos básicos e fundamentais do comportamento humano, como a sociabilidade, o reconhecimento dos pares, os laços afetivos, dentre outros. A compreensão do processo da oikeiosis humana é de grande importância para compreender o processo que levaria o ser humano à felicidade, que pode ser entendida como resultado da apropriação, levando a viver de acordo com a natureza, ou seja, viver de acordo com sua própria natureza e com a natureza universal ${ }^{9}$.

Dinucci, em seu artigo Koinonia, afirma que, ao inclinar-se para o parentesco divino e para a racionalidade e ao obter, por esse meio, ciência do grande sistema cósmico do qual faz parte, o ser humano passa a ter também uma visão comunitária da realidade, apropriando-se afetivamente não apenas dos que são consanguíneos e próximos, mas do Cosmos como um todo. Entretanto, aquele que não consegue transcender seu lado carnal adquire uma visão egoísta, limitada, antissocial, amoral ou imoral da realidade. Não se apropria daquilo que pode efetivamente, como ser humano, se apropriar. Não torna seu o mundo e não se vê como parte dele. Em suma: limitando-se à oikeiosis eklektike, o ser humano não assume seu papel no mundo, mas, ao ascender à oikeiosis hairetike, acaba por ampliar o alcance da própria oikeiosis sterktike (DINUCCI, 2020, p. 83). Continuando esta mesma linha de raciocínio podemos aprofundar mais, pois:

[..] A partir disso, podemos dizer que é preciso compreende a afirmação epictetiana da dupla natureza humana (ou seu duplo parentesco) não platonicamente, mas a partir da doutrina estoica da oikeiosis, significando uma dupla possibilidade para cada ser humano: manter-se no nível da oikeiosis eklektike, própria dos animais irracionais, tornando-se egoísta e incapaz de uma visão abrangente, amorosa e comunitária da humanidade e do Cosmos, ou alçar-se à oikeiosis hairetike, pela qual tem acesso às ações convenientes próprias a cada relação, tornando-se sociável, comunitário e cidadão cósmico. As relações são estabelecidas através de impulsos provenientes dos desdobramentos da oikeiosis e, portanto, oriundos da natureza individual. (DINUCCI, 2020, p. 85-86).

Em suma, a oikeiosis humana se desdobra em cinco etapas: o animal percebe a si mesmo logo após o nascimento, sente afeição por si, na interação com os objetos externos o animal é levado pelo impulso a escolher as coisas que favorecem sua existência. Nos seres humanos, com a formação da capacidade racional, o fator dirigente das ações deve ser a racionalidade, com o objetivo de viver segundo nossa natureza racional, buscando a obtenção dos bens morais, para que possamos ter uma vida virtuosa, ou seja, de acordo com a natureza.

\section{INDIFERENTES (ADIAPHORA)}

\footnotetext{
${ }^{9}$ Ver Epíteto - Diatribe. 1.6. p. 12-22.
} 
Vimos, na doutrina da oikeiosis, que a excelência humana consiste em viver de acordo com a natureza, em adesão total à ordem universal. Sendo a razão o que nos diferencia dos animais (não racionais) e que nos torna humanos, o bem supremo do ser humano seria viver sua vida pautada pela racionalidade. Portanto o bem para nós está relacionado ao correto uso de nossa faculdade racional, que nos possibilita buscar o que nos é próprio e necessário para nosso pleno desenvolvimento e nos leva a rejeitar tudo que é prejudicial. Dessa maneira, agimos em acordo com nossa natureza e estamos em comunhão com o cosmos e, assim, podemos alcançar a felicidade. Dentre as coisas boas estão relacionadas àquelas que se ligam às virtudes, como sabedoria, justiça, coragem e autodisciplina, enquanto as ruins incluem aquelas que são os opostos das virtudes e se relacionam aos vícios ${ }^{10}$ : a saber, ignorância, injustiça, covardia e indulgência. Podemos concluir que, para os estoicos, há no mundo coisas que são boas e más para a felicidade humana. Eles ainda acrescentam que, entre as coisas do mundo, há uma terceira categoria de valor que eles chamam de Adiáfora ( $\alpha \delta i \alpha ́ \varphi \circ \rho \circ \varsigma)$, isto é, indiferentes, quais sejam, todas as coisas que não contribuem nem para a virtude e nem para a maldade. Por exemplo, a riqueza, a saúde podem ser utilizadas tanto para o bem quanto para o mal; são, portanto, indiferentes para a felicidade dos homens, não porque deixam os homens indiferentes (na realidade suscitam o seu desejo), mas porque a felicidade consiste somente no comportamento racional, isto é, na virtude. (LAÉRCIO, 1988, p. 103-104). O estoico é indiferente às coisas externas, por estas não serem fundamentais para o desenvolvimento humano ou por não contribuírem para nossa felicidade. Epicteto sintetiza a divisão entre bens, males e indiferentes no estoicismo da seguinte forma:

\begin{abstract}
Das coisas existentes, algumas são encargos nossos [1]; outras não. São encargos nossos o juízo, o impulso, o desejo, a repulsa - em suma: tudo quanto seja ação nossa. Não são encargos nossos o corpo, as posses, a reputação, os cargos públicos em suma: tudo quanto não seja ação nossa. (2) Por natureza, as coisas que são encargos nossos são livres, desobstruídas, sem entraves. As que não são encargos nossos são débeis, escravas, obstruídas, de outrem. (3) Lembra então que, se pensares livres as coisas escravas por natureza e tuas as de outrem, tu te farás entraves, tu te afligirás, tu te inquietarás, censurarás tanto os deuses como os homens. Mas se pensares teu unicamente o que é teu, e o que é de outrem, como o é, de outrem, ninguém jamais te constrangerá, ninguém te fará obstáculos [...]. (DINUCCI; JULIEN, 2012, p. 15)
\end{abstract}

\footnotetext{
${ }^{10}$ VÍCIO (gr. какía; lat. Vitium; in. Vice, fr. Vice, al. Laster, it. Vizio). 1. O contrário da virtude nos vários significados deste termo. Com referência ao conceito aristotélico-estoico de virtude como hábito racional da conduta, o V. é um hábito (ou uma disposição) irracional. Neste sentido, a palavra V. só se aplica às virtudes éticas. Com referência às virtudes dianoéticas ou intelectivas, V. significa simplesmente a falta delas: falta que, segundo Aristóteles, é vergonhosa somente como participação malograda nas coisas excelentes de que participam todos os outros, ou quase todos, ou pelo menos os que são semelhantes a nós, ou seja, os que têm nossa idade ou que são de nossa cidade, família ou classe social (Ret., II, 6, 1383b 19; 1384a 22)
} 
O fator decisivo para o estoicismo não são os fatos, mas a atitude com que estes são encarados. A ênfase é colocada na decisão e na escolha, não nos resultados nem na realização. Segundo Epicteto, tudo que existe no mundo está dividido entre as coisas que estão sob nosso encargo, e estas estariam em nosso campo de ação livre que é nossa interioridade, subjetividade e, portanto, sujeitas à nossa escolha e à da nossa razão. Dessa maneira está absolutamente sob nosso encargo nos tornarmos virtuosos ou nos inclinarmos para os vícios ${ }^{11}$.

A partir da compreensão do que está sob nosso encargo, podemos estabelecer uma atitude segundo a razão, a qual nos levaria a um maior nível de eficácia de nossas ações. Na busca pelo aperfeiçoamento moral devemos nos proteger de ações prejudiciais, nos afastando das paixões, procurando aprender com os erros e buscar sempre nosso aperfeiçoamento moral, nos aproximando da virtude ou do que é virtuoso para nossa própria felicidade. A grande tarefa é saber o que podemos realizar e como devemos agir diante das falsas opiniões que temos sobre as coisas externas e das nossas paixões, que são o nosso grande obstáculo no processo de aproximação à virtude e à felicidade. Elas turvam nossa faculdade racional, impossibilitando o correto assentimento às representações que nos chegam de fora e de nossas próprias representações, nos afastando da correta compreensão dos acontecimentos e nos impossibilitando agir corretamente. Portanto, as paixões são fruto de um (mal) assentimento, por isso devemos evitar que elas se instalem, pois, uma vez instaladas perdemos o controle sobre elas. Devemos nos utilizar da nossa racionalidade para conhecer melhor o que nos é exterior e a nós mesmos. Neste processo, será possível ao ser humano substituir as impressões falsas que temos em nossa interioridade acerca das coisas externas, aperfeiçoando nossa compreensão de nós mesmos e do mundo ${ }^{12}$.

Os estóicos partem da ideia de que dado o assentimento a uma representação, seguese de imediato o impulso de agir. Nesse sentido a revisão dos nossos julgamentos sobre as coisas deve ser exercício ético constante, pois muitos dos nossos vícios estão pautados em um erro de julgamento. Muitas vezes tomamos algo que não pertence ao âmbito da virtude como o bem. Para os estoicos, o único bem é aquele que participa da razão.” (SANTOS, 2015, p. 34).

\footnotetext{
${ }^{11}$ Segundo Dinucci, “as coisas sob nosso encargo, ou sob nosso controle, podem ser boas ou más e podem ser escolhidas, enquanto as que não estão sob nosso encargo, ou não estão sob nosso controle, não são nem boas nem más, mas indiferentes e não podem ser escolhidas" (DINUCCI, 2020, IN: https://socientifica.com.br/oquesao-coisas-indiferentes-no-estoicismo-de-epicteto-e-qual-a-atitude-correta-diante-delas/. $\quad$ Acesso em 12.02.2021, às 16h24).

${ }^{12}$ Dentro da compreensão estoica das representações a maneira como é compreendida as representações não está relacionado em apenas conhecer os objetos, ou os acontecimentos externos através da nossa sensibilidade, elas também estão relacionadas ao modo como representamos o mundo.
} 
Os estóicos subdividem os indiferentes em três tipos distintos: No primeiro tipo temos os que eles consideram que estão de acordo com a natureza e são, portanto, preferíveis, como, por exemplo, viver de acordo com nossa racionalidade. No segundo momento, temos o que eles chamam de absolutamente indiferentes, porque não estão nem contra nem a favor da natureza (se o número de cabelos é par ou ímpar, como exemplificado por Diógenes Laércio). No terceiro e último caso, nos apresentam os indiferentes que devem ser rejeitados por não estarem de acordo com a natureza. ${ }^{13}$

Para obtermos a reta compreensão das coisas e, assim, evitar as falsas opiniões e o domínio das paixões sobre nossas ações, devemos constantemente estar vigilantes quanto ao modo como devemos agir. Para isso é necessária uma revisão de nossos julgamentos. Portanto, o exercício ético se dá nesse processo de revisão dos julgamentos, e a ação passa pelo crivo da racionalidade, possibilitando o que os estoicos chamam de representação compreensiva $^{14}$ (phantasía kataleptiké). É necessário ainda que nossos sentidos sejam saudáveis e que não haja nenhum obstáculo que possa interferir no processo de compreensão cataléptica, quando há o assentimento racional o ser humano passa a agir integrado segundo a razão universal.

As coisas que não estão sob nosso encargo, ou seja, as que não estão sob o nosso poder, concentram-se fora de nós. São tudo aquilo que não possui valor em si mesmo, por exemplo, saúde, pobreza, má reputação, propriedades etc. Estas coisas estão postas como elementos do mundo e, portanto, fora do nosso controle. Ainda citando Epicteto:

As coisas não inquietam os homens, mas as opiniões sobre as coisas. Por exemplo: a morte nada tem de terrível, ou também a Sócrates teria se afigurado assim, mas é a opinião a respeito da morte de que ela é terrível - que é terrível! Então, quando se nos apresentarem entraves, ou nos inquietarmos, ou nos afligirmos, jamais

\footnotetext{
${ }^{13}$ A categoria dos indiferentes possui valor relativo, somente o homem sábio será capaz de determinar se uma ação será preferível ou não.

${ }^{14}$ A alma especificada no homem tem, à diferença de outras almas, uma potência nomeada lógos, e é exatamente esse núcleo teórico da escola que propicia compreender o que é a representação compreensiva e seu páthos, bem como as páthe que podem prejudicar a alma, essas sim, que devemos afastar, pois nos trazem dificuldades. A alma tem muitas potências, dirá Crisipo, o estoico que estruturou logicamente as teses de Zenão de Citium, o fundador da Stoa, e há uma força ativa na alma que recebe o nome de synkatáthesis (assentimento). Essa dýnamis anuncia a presença de algo que se impôs à alma como presença, a que se nomeia representação (phantasía). O que é isso que se dá a mim? Como julgá-lo? A partir daí, um exercício árduo será feito pelo poder logístico da alma, para conhecer as condições dessa presença e poder aceitá-la como "x", ou seja, confirmá-la, assenti-la. Assim fazendo, essa presença pode ser recebida como phantasía kataleptiké, termo traduzido por representação compreensiva. Essa representação é o critério para o julgamento verdadeiro (Cícero, SVF 1.61, 66 e 68), pressupõe a presença de algo e o cuidadoso trabalho para assentir a esse algo como evidente, certo, já que recebemos múltiplas presenças na alma e de vários modos. Como diz Crisipo, não se deve assentir a todas sem um trabalho laborioso do logístico (Sext. Emp. Math. 8.397). (Representação compreensiva: critério de verdade e virtude no Estoicismo Antigo RACHEL GAZOLLA Pontifícia Universidade Católica de São Paulo Brasil, Classica (Brasil) 19.2, 187-195, 2006).
} 
consideremos outra coisa à causa, senão nós mesmos - isto é: as nossas próprias opiniões (EPITETO apud DINUCCI; JULIEN, 2012, p. 13-14).

Podemos observar, na citação, que, para Epicteto, o que nós temos como entraves são as opiniões que temos a cerca das coisas, essas opiniões são responsáveis por nossa inquietação diante desses elementos externos, não são as coisas em si que nos perturbam a alma, mas é nosso juízo de valor atribuído a esses componentes que nos perturbam. Nesse sentido, as coisas exteriores são indiferentes, pois o que nos causa sofrimento são as nossas opiniões, que são fruto da ignorância que temos das coisas, dos acontecimentos e de nós mesmos. Há uma necessidade de conhecer para agir, e essa relação do saber e agir é possível apenas pelo correto uso de nossa faculdade racional. A ética, fruto desse saber-agir em coerência com a natureza, não é tarefa fácil. Temos a razão como ferramenta no processo de juízo e escolha, sendo ela o nosso maior bem. Devemos pautar nossas escolhas a partir de nossa racionalidade, sendo criteriosos quanto às nossas próprias ações, pois é a razão que nos ensina e define aquilo que devemos fazer e evitar. Sobre os indiferentes Diógenes Laércio nos diz que:

[...] Indiferentes quer dizer o que não põe em movimento nem a inclinação, nem a repulsão, como ter sobre a cabeça cabelos em número par ou ímpar[...] As coisas indiferentes são umas a preferir, outras a não preferir: são preferíveis (proegména) as que têm um valor, e não preferíveis (aproegména) as que são a desdenhar... Um valor é um certo poder secundário, aquele que ajuda a uma vida conforme à natureza, por exemplo, aquela ajuda que a riqueza ou a saúde podem trazer para viver conforme à natureza [...] (LAÉRCIO apud GONZALLA, 2006, p. 191).

Como vimos, dentro da categoria dos indiferentes os estoicos acrescentam uma subdivisão entre os que são preferíveis e os não preferíveis. Podemos destacar como preferíveis a saúde em relação à doença. Porém para os estoicos a saúde teria um valor secundário, visto que não necessariamente possuindo-a seremos felizes ou alcançaremos a virtude. Sabemos da importância de sermos saudáveis, e devemos tomar todos os cuidados de preservação desta, porque é desejável ser saudável e não doente. Porém ter saúde não é sinônimo de felicidade ou de ser virtuoso, e também ela não é um meio para estes fins. Os indiferentes não trazem valores absolutos em si, mas estão relacionados quanto ao que nos é apropriado ou não, ou ainda como podemos usufruir deles para nosso bem e o de outrem. Assim, os indiferentes ganham uma conotação valorativa quando nos movemos em sua direção, na maneira como utilizamos esses objetos para um determinado fim. Seu valor dependente da escolha e utilidade que cada um de nós atribuirmos. Retomando o exemplo da saúde, podemos perceber que ela pode ser um meio para nos beneficiarmos ou ser utilizada 
para prejuízo de nós mesmos e dos outros. Em suma, os indiferentes têm um valor secundário para nossas ações e/ou nossa felicidade e que, portanto, não interferem no progresso moral dos indivíduos. $\mathrm{O}$ reconhecimento dos indiferentes ${ }^{15}$ se torna um meio para o aperfeiçoamento moral: devemos entender sua funcionalidade e utilidade dentro das circunstâncias para que a prática da virtude possa ser exercida de maneira a conquistarmos nossa liberdade interior. $\mathrm{O}$ estoico não ignora o que o cerca, ele se apropria destes fatos para que possa interagir de modo apropriado, ou seja, utilizando sua faculdade racional pra compreender o modo apropriado de agir em cada circunstância, tanto consigo quanto com seus semelhantes e na resolução de problemas que possam surgir.

A distinção dos indiferentes nos favorece para a prática da ética por excelência, pois é na capacidade de se fazer boas escolhas que o humano se revela um proficiens, ou seja, aquele que está em processo de desenvolvimento e aperfeiçoamento moral.

\section{CONSIDERAÇÕES FINAIS}

Podemos pensar que dentro do processo de desenvolvimento humano, a oikeiosis, é a base para compreendermos o nosso comportamento, o modo adequado de agir, e pôr fim a ética estoica. Nesse processo os seres passam por uma apropriação de si mesmos, ou seja, tomam consciência de si, ao mesmo tempo em passam pela apropriação de si mesmos, desenvolvem pelo impulso a consciência de suas partes, e dos objetos externos esse fluxo continuo entre o ser e seu corpo estabelece a consciência de si e apropriando-se de suas capacidades segundo sua própria natureza, é direcionado pelo impulso a buscar o que lhe é próprio e benéfico a seu desenvolvimento, naturalmente o ser desenvolve a repulsa por tudo aquilo que lhe é contrário segundo sua natureza. No desenvolvimento dos seres humanos, entre os sete e catorze anos a faculdade racional se instala e diferente dos seres não-racionais,

\footnotetext{
${ }^{15}$ De acordo com a reflexão de Aldo Dinucci, "Os materiais são indiferentes, mas o uso deles não é indiferente. Como então alguém se manterá simultaneamente equilibrado e sem agitação, simultaneamente agindo como cuidado e não ao acaso nem sendo arrastado? Se imitar dos jogadores de dados. Os números são indiferentes, os dados são indiferentes: então sabes qual número está para sair? Fazer uso do número que cai com cuidado e habilidade, eis aí a minha tarefa. Do mesmo modo, portanto, o principal sobre a vida é isto: distinguir e separar as coisas e dizer: 'As coisas exteriores não estão sob meu encargo, a capacidade de escolha está sob meu encargo. Onde buscarei o bem e o mal? Nas minhas coisas'. Quanto às coisas de outrem, jamais as chames de boas ou más, benéficas ou nocivas, ou qualquer outro semelhante. E então? Devo fazer uso das coisas de modo descuidado? De modo algum, pois isso, por sua vez, é um mal para a capacidade de escolha e, desse modo, contrário à natureza. Mas simultaneamente com cuidado, porque o uso não é indiferente, simultaneamente com equilíbrio e sem agitação, porque a matéria é indiferente. Pois onde há o que não é indiferente, aí não se pode ser obstaculizado nem constrangido. Onde sou obstaculizado e constrangido, a obtenção não está sob o meu encargo, nem é boa ou má, mas o uso é bom ou mau e está sob o meu encargo". (DINUCCI, 2020, IN: https://socientifica.com.br/o-que-sao-coisas-indiferentes-no-estoicismo-de-epicteto-e-qual-a-atitudecorretadiante-delas/. Acesso em 20.08.2020)
} 
os quais são guiados pelo impulso, nós devemos ser orientados por nossa razão , como dissemos o impulso está presente por toda a vida dos seres, porém , para nós que possuímos a razão e portanto, temos a capacidade de escolha, e que nos coloca como agentes morais no mundo, devemos nos apropriar de nossa natureza racional e agir segundo esta mesma natureza, se obtemos está capacidade, estamos destinados a viver de acordo com nossa natureza e a inteligência universal.

\section{REFERÊNCIAS}

ANTISERI, Dario; REALE, Giovani. História da Filosofia: Filosofia Pagã Antiga. 3. ed. São Paulo: Paulus, 2007.

DINUCCI, Aldo. Koinonia cósmica e antropológica em Epicteto. In: POMBALINA, Coimbra University Press: Coimbra/Portugal, 2020.

. Apresentação e tradução da Diatribe de Epicteto 1.8. In: PROMETEUS, Universidade Federal de Sergipe (UFS), São Cristovão/SE, v. 7, p. 289-295, 2014.

DINUCCI, Aldo; JULIEN, Alfredo. O encheirídion de Epicteto. São Cristóvão: Editora UFS, 2012.

GAZOLLA, Rachel. O oficio do filósofo estoico: o duplo registro da stoa. São Paulo: Loyola, 1999.

GOURINAT, J. B.; BARNES, J. (orgs.). Ler os estoicos. Tradução Paula S. R. C. Silva. São Paulo: Edições Loyola, 2013.

LAÉRCIO, Diógenes. Vidas e doutrinas dos filósofos ilustres. Tradução do grego, introdução e notas de Mario da Gama Cury. Brasília: Editora Unb, 1988.

OLIVEIRA, Fernanda Lopes de. A tanatologia em Epicteto. Porto Alegre/RS: Editora Fi, 2018.

RADICE, Roberto. Estoicismo. Tradução Alessandra Siedschlag. São Paulo: Ideias \& Letras, 2016.

REALE, Giovanni. La filosofia di Sêneca come terapia dei mali dell'anima. 5. ed. Milano: Bompiani, 2004

História da filosofia antiga. São Paulo: Loyola, 1994.

RIBEIRO, Luís Felipe Bellintani. História da Filosofia I. Florianópolis: EdUFSC/EaD, 2008.

SANTOS, Aryane Raysa Araújo dos. O Conceito de Firmeza de Alma nas Cartas a Lucílio de Sêneca, 2015. Dissertação (Mestrado). Programa de Pós-Graduação em Ética e Epistemologia, Ciências Humanas e Letras, Universidade Federal do Piaui (UFP), Teresina/PI, 2015. 